\title{
The Effectiveness of a Counseling Program onDevelopingthe Nutritional Awareness of Pupils with Learning Disabilities at the Elementary Stage in Najran
}

\author{
Nagafa Rezk Abd Elgleel Abd Elnaby ${ }^{1, *} \&$ Fadya Rezk Abdelgalil Abdelnaby ${ }^{2}$ \\ ${ }^{1}$ Department of Home Economics, Najran University, Najran, KSA \\ ${ }^{2}$ Department of Special Education, Najran University, Najran, KSA \\ *Correspondence: Department of Home Economics, Najran University, Najran, KSA. E-mail: nanarzk@hotmail.com
}

The study is funded by the Deanship of Scientific Research at Najran University and holds decision number NU/SHED/14/120

Received: July 25, 2016

Accepted: October 13, 2016 Online Published: October 19, 2016

doi:10.5430/wje.v6n5p64

URL: http://dx.doi.org/10.5430/wje.v6n5p64

\begin{abstract}
The study aimed at investigating the efficacy of a counseling program on developing the nutritional awareness of pupils with learning disabilities at the elementary stage in Najran, KSA. The sample consisted of (20) pupils distributed equally to two groups, experimental and control. The scale of Khalil (2003) for the economic, social, and cultural level, in addition to a questionnaire for the nutritional awareness that was developed by the researchers, were used to achieve the aim of the study. The study concluded that the developed program was effective in enhancing the nutritional awareness of the pupils with learning disabilities at the elementary stage.
\end{abstract}

Keywords: counseling program; pupils with learning disabilities; nutritional awareness; food habits

\section{Introduction}

The field of learning disabilities is one of the most important areas where differences between individual sexist. Although individuals with learning disabilities look normal as well as others, they, in fact they suffer from clear deficits in more than one aspect of learning areas. The use of learning disabilities concept started in (1960) to describe "all the disabled or as an alternative for children of simple cerebral damage". But in (1962) Kirk used the concept to describe "a group of children who have at most moderate intelligence without any other disabilities, whether sensory, physical, or mental", but their actual achievement does not fit the general mental capabilities they have, (Mohammed, 2006).Learning disability is linked to academic achievement capability. The problem does not appear before children's enrolment in school where symptomsofacademic failure begin to appear during discussions, in addition to their failure to do what their normal peers do such as assignments causing a set of academic achievement problems for them, (Al-Kashef and Mohammed, 2006). Attention difficulty, cognition, and memory head the many difficulties to which pupils with learning disabilities are exposed, (Boerema, 2011).At normal and ordinary schools, all learners are required to do homework and assignments despite the individual differences among them. Accordingly, more problems may face pupils with learning disabilities while doing their assignments, (Polloway, et.al., 1992).The child with a learning disability is, at least normal, of intelligence. Consequently, he/she is more aware of the causes of his failure at school and feels the reflectionof this failure on his family. Such awareness generates emotional effects within $\mathrm{him} / \mathrm{her}$ because of his/her inability to change his/her study status. Therefore, much of his/her, mental and emotional power is used out and causes disorders that will be clear on his/her overall character, (Al-Zayyat, 1988).

On the other hand, cognitive growth and mental development at childhood are affected by both internal and external factors. Good nutrition is one of the factors that work on the activation of the child's intellectual activity. It also contributes to the development of his/her learning and academic achievement abilities, (Al-Takrouri\&Al-Masri, 1997) and (Wahba, 1998).Proper nutrition provides children with activity, endurance, ability to pay attention and focus, and 
attention to work and participate positively. Improper nutrition, on the contrary causes fast fatigue, inability to focus for a long time, irritability and lethargy (Saba, 2010).Research has proved that food has a clear impact on children's mentality and attitudes. It provides them with complex vitamin B, especially (B1), which plays an important role in maintaining health, nerves, and the ability to pay attention, achieve and decreases fatigue,(Yousef,1994). Pollitt, et.al. (1981) pointed out that brain functions may be affected by the child's nutritional status and way at breastfeeding stage, intellectual and behavioral skills, and physical activity.Beaulieu \&Ossenfrt (1994) and El-Shafe'i (1998) emphasized that food has a vital role in maintaining integrity of body and developing brain's capacity to retain, comprehend, and be watchful. Pumpkins, for instance contains active substances that stimulate and strengthen memory and develop cells or brain gyri, which are responsible for retention and comprehension. Klenman, et. al. (2002) proved an improvement in the academic achievement along with an improvement in the child's conduct and school attendance after six months of eating a meal that contained (50\%) of the recommended food requirements. Alaimo, et.al. (2003) found a decrease in children's' between (6-12) mathematics skills correlated with a decrease in food efficiency.

Food affects one's learning behavior and achievement through several basic rules including lack of food, intake nutrients, excessive in intake food, or eating certain types continuously. Besides, the eating habits themselves might be wrong and consequently result in poor nutritional status and morbidity. Mohammed (1985) revealed a correlation between verbal and practical IQ, on one hand, and the level of hemoglobin in blood, on the other hand. Aboud (2000) discovered differences between bad nutrition students and normal ones on the IQ and aggressive behavior scale in favor of the normalones. Miryah (2012) showed a negative relationship between malnutrition and academic achievement of learners, while there was a positive relationship between poor nutrition and learner's eating habits. Fredric (1981) revealed that there are factors, which help the spread of malnutrition among Saudi society such as poor eating habits resulting from not diversifying intake food varieties. Khaled \&Sa'eed (2010) illustrated that about (25\%) of children who ignore breakfast consume less than (50\%) of the recommended amounts of calories, vitamin $\mathrm{C}$, Calcium and Iron. Ignorance of breakfast meal affects children mental abilities and academic achievement. Craig (1986) mentioned that some changes in the mental performance functions take place after an hour of having one's breakfast. Benton \& Parker (1998) and Michaud, et.al. (1991) asserted the fact that having foods of high calories at breakfast results in a direct impact on the efficiency of memory and level of glucose in blood. Therefore, it is preferable to have balanced qualitative and quantitative meals. None of the meals should be ignored, especially for children to help body have all its requirements of nutrients and energy without excess or negligence. There should be a focus on nutrients related to intelligence, mental abilities, brain growth, and cognitive functions such as Iron, Iodine, Zinc, Folic acid and essential fatty acids. Gordon (2003) for instance showed that shortage in Iron might affect brain cells and neurons causing brain damage or oxygen shortage. Zhang, et. al. (2005) added that essential fatty acids contribute to performance improvement correlated with intelligence while cholesterol intake is correlated with performance decline. Gibson \& Green (2002) argued that carbohydrates-rich and protein-poor meal can be sedative and removes anxiety, whereas protein-rich meal can be exciting and increases movement and attention. Scrimshaw (1998) believed that having the essential food requirements of protein and calories during the child's first years improves his cognitive performance. That is, each person should identify foodstuff; required types, ingredients, and quantities; the benefits of each type for health; what happens if it increases or decreases; where it is found; and how to benefit from it. He/she should also understand its interactions and integrations with other food elements and alternatives in order to plan the best food system, (Shalabi, 2001). Nevertheless, many studies like Shehda (1992), Beaulieu \&Ossenfrt (1994) and Sherratt (1996) emphasized on food awareness decrease among schoolchildren. Soroor (1994) and Suleiman \&Hasaneen (1997) mentioned that disease is the result of food culture shortage and awareness. They all recommended the importance of working on disseminating food culture and developing food awareness among all society members. In addition, programs of food awareness at early stages should be applied and continue during all learning stages.

In conclusion, nutrition education and the development of nutritional awareness are necessary. All institutions, especially those that are related to children at early stages, should be concerned with nutrition and nutritional awareness because accustoming children with hygienic feeding at early ages makes it part of their habits and food conduct when growingolder. If deployment of the nutritional awareness is essential for all children, it is more necessary for children with learning difficulties because of its impact on their bodies and minds. It is important to pay attention to children nutrition, asit is well known that healthy mind in a healthy body. This importance is doubled for female children, as they will be the future mothers and teachers. Therefore, it is essential for them to have proper information and food practices. Hence, the present study seeks to provide pupils with learning disabilities with proper nutrition information and knowledge, in addition to types of foods that have positive or negative impacts in raising their nutritional and academic levels through a counseling program for their nutritional awareness development. 


\subsection{Study Problem}

The problem of the present study lies in these questions:

1. Can training on a counseling program develop the nutritional awareness of pupils with learning disabilities at elementary stage?

2. Can training on a counseling program develop the nutritional awareness of pupils with learning disabilities at elementary stage after the application of the program in the post and reiterated measurements?

\subsection{Aims of the Study}

The present study aims to:

1. Identify the effectiveness of a counseling program in the development of the nutritional awareness of pupils with learning disabilities in the elementary stage.

2. Identify the effectiveness of a counseling program in the development of the nutritional awareness of pupils with learning disabilities in the elementary stage after the application of the program in the post and reiterated measurements.

\subsection{Importance of the Study}

\subsubsection{Theoretical importance}

The theoretical importance of the present study is reflected in an attempt to identify the effectiveness of the counseling program in the development of the nutritional awareness of pupils with learning disabilities at elementary stage and the results that might be helpful to go on research process.

\subsubsection{Applied Importance}

- Application of the program is supposed to be helpful in developing thenutritional awareness of pupils with learning disabilities. It will help them identify and intake balanced food that help them grow properly, which will be reflected in their ability to remember and perform better at school. It will also increase their attention and improve their mental processes.

- The use of the program can be generalized to alleviate some diseases resulting from malnutrition among pupils with learning disabilities and other pupils of special needs as soon as its effectiveness is proved.

\subsection{Questions of the Study}

The present study seeks to answer these questions:

1. Are there significant differences between the mean scores of pupils with learning disabilities with regard to their nutritional awareness in the pre and post application of the counseling program?

2. Are there significant differences between the mean scores of pupils with learning disabilities in the experimental and control groups with regard to their nutritional awareness in the post measurement?

3. Are there significant differences between the mean scores of pupils with learning disabilities in the experimental group regarding their nutritional awareness in the post and reiterated measurements?

4. Are there significant differences between the mean scores of pupils with learning disabilities in the control group regarding their nutritional awareness in the pre and post measurements?

\section{Methodology}

\subsection{Study Approach}

The descriptive and quasi-experimental approaches were used in the study because of their appropriateness to the aims of the present study.

\subsection{The Population}

Population of the present study consisted of all pupils with learning disabilities at Iskan School in the Directorate of Education at Najran, KSA.

\subsection{The Sample}

The sample consisted of (20) pupils with learning disabilities at Iskan School in the Directorate of Education at Najran, KSA. They were divided into experimental and control group of (10) pupils in each. 


\subsection{Participants' Homogeneity}

Homogeneity between all participants in the experimental and control groups was accounted for regarding their age; IQ level; economic, social and cultural level using the scale of Khalil (2003); and their scores on nutritional awareness in the pre application. Results showed no significant differences between participants in both groups. In other words, mean scores of participants in both groups were homogeneous regarding all study variables in the pre-application. Z. value was insignificant for all variables, which illustrates a high degree of homogeneity between both groups.

\subsection{Instruments}

\subsubsection{Nutritional Awareness Questionnaire}

The questionnaire consisted of (50) items distributed to three fields that express nutritional awareness for pupils namely, food habits (6 items); food beliefs (6 items); and knowledge related to the resources and functions of food elements including carbohydrates, proteins, fats, mineral salts, vitamins, and water (38 items). The questionnaire was fit for individual and group application. Items' simplicity and clarity for participant pupils were accounted for. Three levels of answers were attached to each item (agree, neutral, do not agree). The questionnaire was presented to (10) specialists in the fields of special education and nutrition to check items' drafting and choose the best ones that measure the nutritional awareness of pupils with learning disabilities. Required modifications were made by adding or deleting some items.

\subsubsection{Questionnaire Marking}

Items in the questionnaire were corrected as follows:

Positive items were given (3-2-1) for agree, neutral, and do not agree respectively. Negative items were assigned (1-2-3) for agree, neutral, and do not agree respectively. Diagnosis was done regarding the total degree and the low degree that the pupil got while expressing her nutritional awareness degree.

\subsubsection{Questionnaire Reliability}

To calculate the reliability coefficientof the nutritional awareness questionnaire, test and retest; equal haves (Spearman Brown-Guttmann); and Cronbach Alpha were used depending of SPSS program. Table (1) illustrates the questionnaires reliability coefficients.

Table 1. Correlation Coefficients of Nutritional Awareness Questionnaire

\begin{tabular}{ccccc}
\hline Test and retest & \multicolumn{3}{c}{ Split-half } & \multirow{2}{*}{ Cronbach alpha } \\
\cline { 2 - 4 } & Spearman & Guttmann & \\
\hline 0.89 & 0.88 & 0.91 & 0.93 \\
\hline
\end{tabular}

Significant at $(\alpha=0.01)$

\subsubsection{Questionnaire Internal Consistency}

Values of correlation coefficients ranged from $(0.57-0.89)$, which were acceptable and significant at $(\alpha=0.01)$ indicating an internal consistency.

\subsubsection{Counseling Program}

A counseling program for developing the nutritional awareness of pupils with learning disabilities at Najran, KSA was developed.

\subsubsection{Techniques Used}

A set of techniques was used such as, lecture; discussion; and emphatic training that involves many strategies like teaching, feedback, behavioral exercise or role-play, modeling, social reinforcement, training on relaxation; homework; reinforcement; and PowerPoint presentations.

\subsubsection{Aims of the Program}

The developed program aims to develop the nutritional awareness of learning disabilities pupils through amending the negative ideas and refuting the irrational thoughts using a set of techniques. Hence, aims of the program can be of two kinds:

1. A counseling aim as the program aims to develop the nutritional awareness through some counseling artistic steps. 
2. A preventive aim through empowering counseling group members some behaviors that enable them to face malnutrition diseases that pupils may be exposed to because of nutritional awareness decrease.

\subsubsection{The Program's Main Features of the}

1. Program sessions: The developed program consisted of (12) sessions and was applied three times a week for (4) weeks.

2. Counseling method used in the program: the program was implemented in a group work on the counseling group members.

3. Sessions' duration: duration of each session in the program ranged between (45-60) minutes according to its topic, procedures used and sample circumstances.

4. Language of the program: the program was presented in simple language that ranged between colloquial and standard to make it easier for participants to understand the sessions and benefit from them.

5. Stages of program implementation: the program was implemented through five stages namely, preparation, introduction, beginning, application, assessment, and follow-up.

\section{The Pilot Study}

A pilot study for the developed program in the present study was conducted on a number of pupils of learning disabilities who had similar circumstances to the circumstances of the study participants in the experimental group. The aim of the pilot study was to determine the needed time for each session, number of sessions required to achieve the study aims, and the used techniques.

\subsection{Place of Sessions}

The program was implemented at the resource room at the selected school.

\subsection{Content of Sessions}

The content was chosen regarding the general and procedural aims of the program and practical procedures including techniques, counseling method, and used aids.

Table 2. Arrangement of the Counseling Program Sessions

\begin{tabular}{|c|c|c|c|}
\hline $\begin{array}{l}\text { Session type } \\
\text { and time }\end{array}$ & Session title & Session aim & Techniques used \\
\hline $\begin{array}{c}\text { Group session } \\
(45-60) \\
\text { minutes }\end{array}$ & $\begin{array}{l}\text { Introduction of } \\
\text { researchers and } \\
\text { guidance group }+ \\
\text { Program preface }\end{array}$ & $\begin{array}{l}\text { - Establish familiarity between researchers and } \\
\text { study sample. } \\
\text { - Familiarizing participants with the program and } \\
\text { giving then a comprehensive idea about the main } \\
\text { steps in light of which guidance sessions will be } \\
\text { carried out. }\end{array}$ & $\begin{array}{l}\text { - Lecture } \\
\text { - Discussion } \\
\text { - Reinforcement }\end{array}$ \\
\hline $\begin{array}{c}\text { Group session } \\
(45-60) \\
\text { minutes }\end{array}$ & $\begin{array}{l}\text { Developing the } \\
\text { awareness of } \\
\text { balanced } \\
\text { nutrition }\end{array}$ & $\begin{array}{l}\text { - Identify the importance of balanced nutrition. } \\
\text { - How to achieve balanced nutrition. } \\
\text { - Identify the concept of malnutrition. } \\
\text { - Identify the causes of malnutrition. } \\
\text { - Identify the awareness of major symptoms of } \\
\text { malnutrition diseases. }\end{array}$ & $\begin{array}{l}\text { - Lecture } \\
\text { - Discussion } \\
\text { - PowerPoint pres. } \\
\text { - Emphatic training } \\
\text { - Reinforcement } \\
\text { - Homework }\end{array}$ \\
\hline $\begin{array}{c}\text { Group session } \\
(45-60) \\
\text { minutes }\end{array}$ & $\begin{array}{l}\text { Developing the } \\
\text { awareness of } \\
\text { water resources } \\
\text { and functions }\end{array}$ & $\begin{array}{l}\text { - Increase the awareness of the resources through } \\
\text { which the body gets water. } \\
\text { - Increase the awareness of water functions inside } \\
\text { the body. } \\
\text { - Increase the awareness of water shortage and } \\
\text { increase. }\end{array}$ & $\begin{array}{l}- \text { Lecture } \\
\text { - Discussion } \\
\text { - PowerPoint pres. } \\
\text { - Emphatic training } \\
\text { - Reinforcement }\end{array}$ \\
\hline
\end{tabular}




\begin{tabular}{|c|c|c|c|}
\hline & & & - Homework \\
\hline $\begin{array}{l}\text { Group session } \\
(45-60) \\
\text { minutes }\end{array}$ & $\begin{array}{l}\text { Develop the } \\
\text { awareness of } \\
\text { some mineral } \\
\text { salts' resources } \\
\text { and functions }\end{array}$ & $\begin{array}{l}\text { - Increase the awareness of the resources of some } \\
\text { mineral salts like zinc, iron, calcium, magnesium. } \\
\text { - Increase the awareness of the functions of some } \\
\text { mineral salts like zinc, iron, calcium, magnesium. } \\
\text { - Increase the awareness of the shortage and } \\
\text { increase of some mineral salts like zinc, iron } \\
\text { calcium, magnesium. }\end{array}$ & $\begin{array}{l}\text { - Lecture } \\
\text { - Discussion } \\
\text { - PowerPoint pres. } \\
\text { - Emphatic training } \\
\text { - Reinforcement } \\
\text { - Homework }\end{array}$ \\
\hline $\begin{array}{l}\text { Group session } \\
(45-60) \\
\text { minutes }\end{array}$ & $\begin{array}{l}\text { Develop the } \\
\text { awareness of } \\
\text { some vitamins' } \\
\text { resources and } \\
\text { functions }\end{array}$ & $\begin{array}{l}\text { - Increase the awareness of the resources of some } \\
\text { vitamins like Vitamin A, B2, B3, B5, B6, B12, } \\
\& D \text {. } \\
\text { - Increase the awareness of the functions of some } \\
\text { vitamins like Vitamin A, B2, B3, B5, B6, B12, } \\
\text { \&D. } \\
\text { - Increase the awareness of the shortage and } \\
\text { increase of some vitamins like Vitamin A, B2, } \\
\text { B3, B5, B6, B12, D. }\end{array}$ & $\begin{array}{l}- \text { Lecture } \\
\text { - Discussion } \\
\text { - PowerPoint pres. } \\
\text { - Emphatic training } \\
\text { - Reinforcement } \\
\text { - Homework }\end{array}$ \\
\hline $\begin{array}{l}\text { Group session } \\
(45-60) \\
\text { minutes }\end{array}$ & $\begin{array}{l}\text { Develop the } \\
\text { awareness of } \\
\text { some proteins' } \\
\text { resources and } \\
\text { functions }\end{array}$ & $\begin{array}{l}\text { - Increase the awareness of the resources of some } \\
\text { proteins. } \\
\text { - Increase the awareness of the functions of some } \\
\text { proteins. } \\
\text { - Increase the awareness of the shortage and } \\
\text { increase of some proteins. }\end{array}$ & $\begin{array}{l}- \text { Lecture } \\
\text { - Discussion } \\
\text { - PowerPoint pres. } \\
\text { - Emphatic training } \\
\text { - Reinforcement } \\
\text { - Homework }\end{array}$ \\
\hline $\begin{array}{l}\text { Group session } \\
(45-60) \\
\text { minutes }\end{array}$ & $\begin{array}{l}\text { Develop the } \\
\text { awareness of } \\
\text { some } \\
\text { carbohydrates' } \\
\text { resources and } \\
\text { functions }\end{array}$ & $\begin{array}{l}\text { - Increase the awareness of the resources of some } \\
\text { carbohydrates. } \\
\text { - Increase the awareness of the functions of some } \\
\text { carbohydrates. } \\
\text { - Increase the awareness of the shortage and } \\
\text { increase of some carbohydrates. }\end{array}$ & $\begin{array}{l}\text { - Lecture } \\
\text { - Discussion } \\
\text { - PowerPoint pres. } \\
\text { - Emphatic training } \\
\text { - Reinforcement } \\
\text { - Homework }\end{array}$ \\
\hline $\begin{array}{l}\text { Group session } \\
(45-60) \\
\text { minutes }\end{array}$ & $\begin{array}{l}\text { Develop the } \\
\text { awareness of } \\
\text { some fats' } \\
\text { resources and } \\
\text { functions }\end{array}$ & $\begin{array}{l}\text { - Increase the awareness of the resources of some } \\
\text { fats. } \\
\text { - Increase the awareness of the functions of some } \\
\text { fats. } \\
\text { - Increase the awareness of the shortage and } \\
\text { increase of some fats. }\end{array}$ & $\begin{array}{l}\text { - Lecture } \\
\text { - Discussion } \\
\text { - PowerPoint pres. } \\
\text { - Emphatic training } \\
\text { - Reinforcement } \\
\text { - Homework }\end{array}$ \\
\hline $\begin{array}{l}\text { Group session } \\
(45-60) \\
\text { minutes }\end{array}$ & Nutrition habits & $\begin{array}{l}\text { - Identify food habits that the study sample often } \\
\text { has. } \\
\text { - Familiarize study sample with the wrong food } \\
\text { habits they have. } \\
\text { - Familiarize study sample with how to replace } \\
\text { wrong food habits by proper ones. }\end{array}$ & $\begin{array}{l}\text { - Lecture } \\
\text { - Discussion } \\
\text { - PowerPoint pres. } \\
\text { - Emphatic training } \\
\text { - Reinforcement } \\
\text { - Homework }\end{array}$ \\
\hline $\begin{array}{l}\text { Group session } \\
(45-60) \\
\text { minutes }\end{array}$ & Food beliefs & $\begin{array}{l}\text { - Identify food beliefs that the study sample often } \\
\text { has. } \\
\text { - Familiarize study sample with the wrong food }\end{array}$ & $\begin{array}{l}\text { - Lecture } \\
\text { - Discussion }\end{array}$ \\
\hline
\end{tabular}




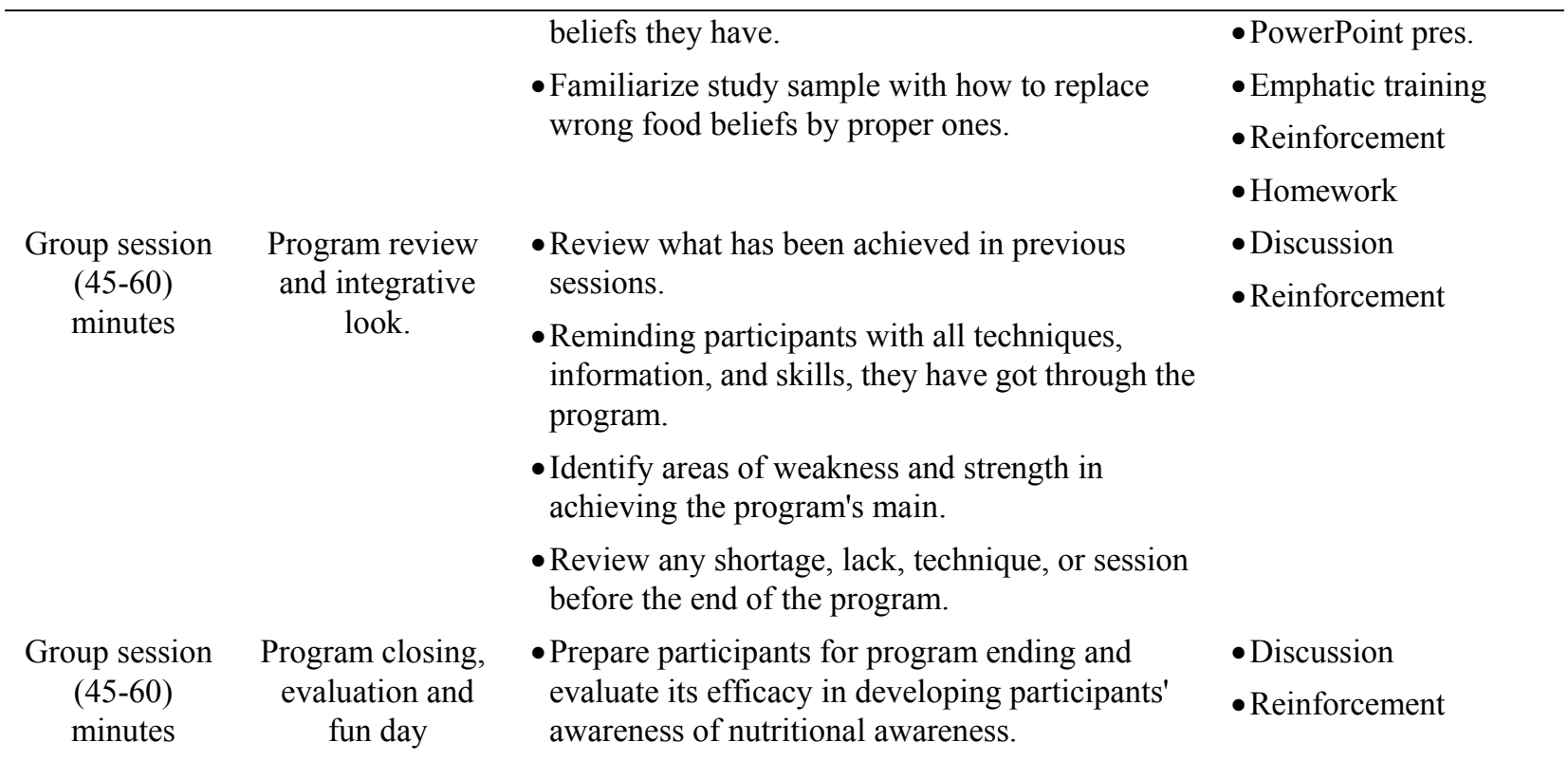

\subsection{Sixth: Statistical Methods}

To analyze data collected, Pearson correlation coefficient, Cronbach alpha, Wilcoxon equation, Mann-Whitney U, descriptive statistics such as mean scores and standard deviations and $\mathrm{T}$. test were used.

\section{Findings and Discussion}

\subsection{Findings Related to the First Question}

To answer the first question "Are there significant differences between the mean scores of pupils with learning disabilities with regard to their nutritional awareness in the pre and post application of the counseling program?" Wilcoxon test for correlated pairs was used. Mean scores of the nutritional awareness of participants in the experimental group were also extracted as illustrated in table (3).

Table 3. Differences between the Mean Scores of Nutritional Awareness of Participants in the Experimental Group in the Pre and Post Measurements

\begin{tabular}{|c|c|c|c|c|c|c|c|c|c|c|}
\hline \multirow[t]{2}{*}{ Variables } & \multirow[t]{2}{*}{ Meas. } & \multirow[t]{2}{*}{$\mathbf{N}$} & \multirow[t]{2}{*}{ M } & \multirow[t]{2}{*}{ SD } & \multicolumn{2}{|c|}{ Positive ranks } & \multicolumn{2}{|c|}{$\begin{array}{c}\text { Negative } \\
\text { ranks }\end{array}$} & \multirow[t]{2}{*}{$\begin{array}{c}Z \text { Z. } \\
\text { value }\end{array}$} & \multirow[t]{2}{*}{ Sig. } \\
\hline & & & & & M & Total & M & Total & & \\
\hline \multirow[t]{2}{*}{ Food habits } & Pre & 10 & 8.8 & 1.316560 & 5.5 & 55 & 0 & 0 & 2.823 & 0.005 \\
\hline & Post & & 15.4 & 1.897370 & & & & & & \\
\hline \multirow[t]{2}{*}{ Food beliefs } & Pre & 10 & 8.6 & 1.264910 & 5.5 & 55 & 0 & 0 & 2.820 & 0.005 \\
\hline & Post & & 14.2 & 1.549190 & & & & & & \\
\hline \multirow[t]{2}{*}{ Water } & Pre & 10 & 8.4 & 1.264910 & 5.5 & 55 & 0 & 0 & 2.871 & 0.004 \\
\hline & Post & & 13.1 & 1.286680 & & & & & & \\
\hline \multirow[t]{2}{*}{ Vitamins } & Pre & 10 & 8.1 & 1.370032 & 5.5 & 55 & 0 & 0 & 2.844 & 0.004 \\
\hline & Post & & 12.6 & 1.349900 & & & & & & \\
\hline \multirow[t]{2}{*}{ Mineral salts } & Pre & 10 & 7.8 & 1.316560 & 5.5 & 55 & 0 & 0 & 2.829 & 0.005 \\
\hline & Post & & 12.5 & 1.581140 & & & & & & \\
\hline \multirow[t]{2}{*}{ Carbohydrates } & Pre & 10 & 7.8 & 1.316656 & 5.5 & 55 & 0 & 0 & 2.824 & 0.004 \\
\hline & Post & & 12.5 & 1.269300 & & & & & & \\
\hline \multirow[t]{2}{*}{ Proteins } & Pre & 10 & 7.9 & 1.197220 & 5.5 & 55 & 0 & 0 & 2.831 & 0.005 \\
\hline & Post & & 12.3 & 1.567020 & & & & & & \\
\hline \multirow[t]{2}{*}{ Fats } & Pre & 10 & 7.7 & 1.636390 & 5.5 & 55 & 0 & 0 & 2.814 & 0.005 \\
\hline & Post & & 12.3 & 1.337490 & & & & & & \\
\hline \multirow[t]{2}{*}{ Total degree } & Pre & 10 & 64.8 & 6.90893 & 5.5 & 55 & $\mathbf{0}$ & $\mathbf{0}$ & 2.814 & 0.005 \\
\hline & Post & & 104.8 & 8.06639 & & & & & & \\
\hline
\end{tabular}


Table (3) shows that there are significant differences between the mean scores of participants in the experimental group on pre and post measurements regarding their nutritional awareness in favor of the post measurement. Calculating the total of the negative ranks, it was found that it was $(0)$ and significant $(\alpha=0.05)$. That is, an increase in the nutritional awareness of pupils of learning disabilities in the experimental group was clearly noticed after the application of the developed program. This increase, of course indicates the efficacy of such program.

\subsection{Findings Related to the Second Question}

To answer the second question "Are there significant differences between the mean scores of pupils with learning disabilities in the experimental and control groups with regard to the nutritional awareness in the post measurements?" Mean scores of pupils' grades in both groups were extracted. Mann-Whitney for asymmetric pairs was used as shown in table (4).

Table 4. Mean Scores of Participants in Both Groups Regarding Nutritional Awareness in the Post Measurement

\begin{tabular}{|c|c|c|c|c|c|c|c|c|c|}
\hline Variables & Measurement. & $\mathbf{N}$ & $\mathbf{M}$ & SD & $\begin{array}{c}\text { Mean } \\
\text { rank }\end{array}$ & $\begin{array}{c}\text { Sum of } \\
\text { ranks }\end{array}$ & Mann-Whitney & $\begin{array}{c}\mathrm{Z} . \\
\text { value }\end{array}$ & Sig. \\
\hline \multirow[t]{2}{*}{ Food habits } & Experimental & 10 & 15.4 & 1.8974 & 15.5 & 155 & 0 & 3.805 & 0.00 \\
\hline & Control & & 8.90 & 1.2867 & 5.50 & 055 & & & \\
\hline \multirow[t]{2}{*}{ Food beliefs } & Experimental & 10 & 14.2 & 1.5492 & 15.5 & 155 & 0 & 3.803 & 0.00 \\
\hline & Control & & 8.80 & 1.4757 & 5.50 & 055 & & & \\
\hline \multirow[t]{2}{*}{ Water } & Experimental & 10 & 13.1 & 1.2867 & 15.5 & 155 & 0 & 3.822 & 0.00 \\
\hline & control & & 8.30 & 0.9487 & 5.50 & 055 & & & \\
\hline \multirow[t]{2}{*}{ Vitamins } & Experimental & 10 & 12.6 & 1.3499 & 15.5 & 155 & 0 & 3.810 & 0.00 \\
\hline & Control & & 8.00 & 1.2472 & 5.50 & 055 & & & \\
\hline \multirow[t]{2}{*}{ Mineral salts } & Experimental & 10 & 12.5 & 1.5811 & 15.5 & 155 & 0 & 3.800 & 0.00 \\
\hline & Control & & 7.50 & 1.1080 & 5.50 & 055 & & & \\
\hline \multirow[t]{2}{*}{ Carbohydrates } & Experimental & 10 & 12.5 & 1.2693 & 15.5 & 155 & 0 & 3.811 & 0.00 \\
\hline & control & & 7.50 & 1.0801 & 5.50 & 055 & & & \\
\hline \multirow[t]{2}{*}{ Proteins } & Experimental & 10 & 12.3 & 1.5670 & 15.5 & 155 & 0 & 3.808 & 0.00 \\
\hline & control & & 7.80 & 1.0328 & 5.50 & 055 & & & \\
\hline \multirow[t]{2}{*}{ Fats } & Experimental & 10 & 12.3 & 1.3375 & 15.4 & 154 & 0 & 3.739 & 0.00 \\
\hline & Control & & 7.90 & 1.2867 & 5.60 & 056 & & & \\
\hline \multirow[t]{2}{*}{ Total } & Experimental & 10 & 104.8 & 8.0664 & 15.5 & 155 & 0 & 3.780 & 0.00 \\
\hline & control & & 64.7 & 5.6578 & 5.50 & 055 & & & \\
\hline
\end{tabular}

Table (4) shows that there are significant differences between the mean scores of participants in both groups regarding the nutritional awareness in favor of the experimental group in the post measurement. Calculated Mann-Whitney $U$ was ( 0$)$ for all fields. It was significant at $(\alpha=0.000)$. That is, there are significant differences between participants' nutritional awareness after the application of the developed program.

\subsection{Findings Related to the Third Question}

To answer the third question "Are there significant differences between the mean scores of pupils with learning disabilities in the experimental group with regard to the nutritional awareness in the post and reiterated measurements?" Wilcoxon test for correlated pairs was used. Mean scores of the nutritional awareness of participants in the experimental group were also extracted as illustrated in table (5). 
Table 5. Mean Scores of Participants' Nutritional Awareness in the Post and Reiterated Measurements

\begin{tabular}{|c|c|c|c|c|c|c|c|c|c|c|}
\hline \multirow[t]{2}{*}{ Variables } & \multirow[t]{2}{*}{ Measurement } & \multirow[t]{2}{*}{ N. } & \multirow[t]{2}{*}{ M. } & \multirow[t]{2}{*}{ SD } & \multicolumn{2}{|c|}{ Positive ranks } & \multicolumn{2}{|c|}{$\begin{array}{l}\text { Negative } \\
\text { ranks }\end{array}$} & \multirow[t]{2}{*}{$\begin{array}{c}\mathrm{Z} . \\
\text { value }\end{array}$} & \multirow[t]{2}{*}{ Sig. } \\
\hline & & & & & M. & Total & M & Total & & \\
\hline \multirow[t]{2}{*}{ Food habits } & Reiterated & 10 & 14.4 & 1.6466 & 3 & 15 & 0 & 0 & 2.060 & 0.039 \\
\hline & Post & & 15.4 & 1.8974 & & & & & & \\
\hline \multirow[t]{2}{*}{ Food beliefs } & Reiterated & 10 & 13.6 & 1.7127 & 2 & 6 & 0 & 0 & 1.604 & 0.109 \\
\hline & Post & & 14.2 & 1.5492 & & & & & & \\
\hline \multirow[t]{2}{*}{ Water } & Reiterated & 10 & 12.7 & 1.3375 & 1.5 & 3 & 0 & 0 & 1.342 & 0.180 \\
\hline & Post & & 13.1 & 1.286 & & & & & & \\
\hline \multirow[t]{2}{*}{ Vitamins } & Reiterated & 10 & 12.4 & 1.3499 & 1.5 & 3 & 0 & 0 & 1.414 & 0.157 \\
\hline & Post & & 12.6 & 1.3499 & & & & & & \\
\hline \multirow[t]{2}{*}{ Mineral salts } & Reiterated & 10 & 7.8 & 1.5811 & 0 & 0 & 0 & 0 & 0 & 1 \\
\hline & Post & & 12.5 & 1.5811 & & & & & & \\
\hline \multirow{2}{*}{$\begin{array}{l}\text { Carbohydrat } \\
\text { es }\end{array}$} & Reiterated & 10 & 7.8 & 1.2649 & 1 & 1 & 0 & 0 & 1 & 0.317 \\
\hline & Post & & 12.5 & 1.2693 & & & & & & \\
\hline \multirow[t]{2}{*}{ Proteins } & Reiterated & 10 & 7.9 & 1.3703 & 1.5 & 3 & 0 & 0 & 1.414 & 0.157 \\
\hline & Post & & 12.3 & 1.5670 & & & & & & \\
\hline \multirow[t]{2}{*}{ Fats } & Reiterated & 10 & 7.7 & 1.3166 & 2 & 6 & 0 & 0 & 1.633 & 0.102 \\
\hline & Post & & 12.3 & 1.3375 & & & & & & \\
\hline Total degree & Reiterated & 10 & 64.8 & 7.1717 & 5.89 & 53 & 2 & 2 & 2.609 & $\begin{array}{l}\text { Not } \\
\text { sign. }\end{array}$ \\
\hline
\end{tabular}

Table (5) reveals no significant differences between the mean scores of participants' nutritional awareness in both groups in the post-reiterated measurements in favor of the post measurement. Negative ranks were insignificant. In other words, nutritional awareness increased among participants in the experimental group, which in turn indicates the effectiveness of the developed program.

\subsection{Findings Related to the Fourth Question}

To answer the fourth question, "Are there significant differences between the mean scores of pupils with learning disabilities in the control group with regard to the nutritional awareness in the pre and post measurements?" Wilcoxon test for correlated pairs was used. Mean scores of the nutritional awareness of participants in the control group were also extracted as illustrated in table (6).

Table (6) shows that there are no significant differences between the mean scores of participants in the control groupin thepre and post measurements regarding their nutritional awareness in favor of the post measurement. Calculating the total of the negative ranks, it was found that it was ( 0$)$ and significant $(\alpha=0.05)$. That is, $Z$. value was insignificant, which means that there is no significant change in the nutritional awareness of participants in the control group during the pre and post measurements. 
Table 6. Differences between the Mean Scores of Nutritional Awareness of Participants in the Control Group in the Pre and Post Measurements

\begin{tabular}{|c|c|c|c|c|c|c|c|c|c|c|}
\hline \multirow[t]{2}{*}{ Variables } & \multirow[t]{2}{*}{ Measurement } & \multirow[t]{2}{*}{ N. } & \multirow[t]{2}{*}{ M. } & \multirow[t]{2}{*}{ SD } & \multicolumn{2}{|c|}{ Positive ranks } & \multicolumn{2}{|c|}{ Negative ranks } & \multirow{2}{*}{$\begin{array}{c}\mathrm{Z} . \\
\text { value }\end{array}$} & \multirow[t]{2}{*}{ Sig. } \\
\hline & & & & & $\mathbf{M}$ & Total & M & Total & & \\
\hline \multirow[t]{2}{*}{ Food habits } & Pre & 10 & 8.9 & 1.2867 & 3.13 & 12.5 & 1 & 2.5 & 1.414 & 0.157 \\
\hline & Post & & 9.4 & 1.3499 & & & & & & \\
\hline \multirow[t]{2}{*}{ Food beliefs } & Pre & 10 & 8.8 & 1.4757 & 1 & 1.5 & 2 & 2.25 & 0.916 & 0.414 \\
\hline & Post & & 8.5 & 1.2693 & & & & & & \\
\hline \multirow[t]{2}{*}{ Water } & Pre & 10 & 8.3 & 0.9487 & 1 & 1 & 2 & 2 & 0.447 & 0.655 \\
\hline & Post & & 8.4 & 1.2649 & & & & & & \\
\hline \multirow[t]{2}{*}{ Vitamins } & Pre & 10 & 8.0 & 1.2472 & 1 & 1 & 2 & 2 & 0.447 & 0.655 \\
\hline & Post & & 7.9 & 1.1973 & & & & & & \\
\hline \multirow[t]{2}{*}{ Mineral salts } & Pre & 10 & 7.5 & 1.0801 & 2.25 & 4.5 & 1.5 & 1.5 & 0.816 & 0.414 \\
\hline & Post & & 7.8 & 1.2293 & & & & & & \\
\hline \multirow[t]{2}{*}{ Carbohydrates } & Pre & 10 & 7.5 & 1.0801 & 1 & 1 & 0 & 0 & 1 & 0.317 \\
\hline & Post & & 7.8 & 1.3166 & & & & & & \\
\hline \multirow[t]{2}{*}{ Proteins } & Pre & 10 & 7.8 & 1.0328 & 1.5 & 1.5 & 1.5 & 1.5 & 0 & 1 \\
\hline & Post & & 7.8 & 1.3166 & & & & & & \\
\hline \multirow[t]{2}{*}{ Fats } & Pre & 10 & 7.9 & 1.2867 & 4 & 8 & 4 & 20 & 1.035 & 0.301 \\
\hline & Post & & 7.4 & 1.0750 & & & & & & \\
\hline \multirow[t]{2}{*}{ Total degree } & Pre & 10 & 64.7 & 5.6578 & 4.67 & 28 & 5.76 & 17 & 0.663 & 0.507 \\
\hline & Post & & 65.3 & 5.7165 & & & & & & \\
\hline
\end{tabular}

\section{Discussion of the Findings}

Findings related to the first two questions asserted the effectiveness of the counseling program in the development of the nutritional awareness of pupils of learning disabilities at Iskan School in Najran, KSA. Comparison of participants' mean scores in the experimental group in the pre and post measurements in addition to the comparison of participants' mean scores in the experimental and control groups in the post measurement were used to detect these differences. Comparisons of participants' awareness mean scores in the experimental group in the post and reiterated measurements did not indicate significant differences, accordingly, it could be claimed that there was an increase in the nutritional awareness of learning disabilities pupils in the experimental group. Comparisons of nutritional awareness mean scores of participant pupils in the control group in the pre and post measurements revealed no significant differences, either. The improvement of and the increase in the participants' nutritional awareness can be due to the contribution of the counseling exercises and techniques that the developed counseling program involved.

\section{Recommendations}

Stakeholders and interested people in the development of the academic achievement of pupils with learning disabilities are recommended to:

1. Pay attention to nutritional awareness in the curriculum at primary stage.

2. Provide training programs for mothers of pupils with learning disabilities about the proper ways of feeding.

3. Prepare programs for food education for teachers of pupils with learning disabilities.

4. Organize workshops and seminars to clarify the relationship between food and academic achievement.

5. Use cognitive therapy program to develop positive behaviors among pupils with learning disabilities. 


\section{Acknowledgment}

The researchers are greatly indebted to the Deanship of Scientific Research at Najran University for funding this study in its decision number NU/SHED/14/120 and for the provision of any required help. They are also indebted to those pupils with learning disabilities who participated in the present study for their cooperation and patience.

\section{References}

Aboud, A. J. (2000). The relationship between Nutritional Regime and Manifestations of Behavior and Intelligence among Elementary Pupils, (Unpublished Ph. D. Dissertation), Graduate Institute for Childhood, Cairo.

Alaimo, K., Olson, C. M., \& Frongillo, J. R. (2003). Food Insufficiency and American School-Aged Children's Cognitive, Academic, and Psychosocial Development. Pediatrics, 108(1), 44-53.

Al-Kashef, I., \& Al-Morsi, M. (2007). Effectiveness of a Training Program to Develop Cognitive Skills of Pupils with Learning Disabilities, International Conference of Learning Disabilities, November 19-22, Riyadh.

Al-Shafe'i, D. M. (1998). Food and Personality. Qatari Journal of Education, 126(27), 294-300.

Al-Takrouri, H., \& Al-Masri, K. (1997). Science of General Nutrition: Fundamentals of Comparative Nutrition. Cairo: Arabic House for Publication and Distribution.

Al-Zayyat, F. M. (1998). Learning Disabilities, Theoretical, diagnostic and therapeutic Foundations. Cairo: Al-Jami'at House for Publishing.

Beaulieu, P., \& Ossenfort, P. (1994). Main Agricultural Food Project Seed. ERIC NO: ED 376014.

Benton, D., \& Parker, P. (1998). Breakfast, Blood, Glucose and Cognition. Am J Clin Nutr01, 67(4), $772-778$.

Boerema, J. A. (2011). An Analysis of Private School Mission StatementPeabody. Journal of Education, 81, $180-202$.

Craig, A. (1986). Acute Effects of Meals on Perceptual and Cognitive Efficiency. Nutrition Review, 44, $163-171$. http://dx.doi.org/10.1111/j.1753-4887.1986.tb07693.x

Fredric, P.H. (1981). Food and Nutrition.Saudi Medical Journal, 2(1).

Gibson, L., \& Green. W. (2002). Nutritional Influences on Cognitive Function and Mechanisms of Susceptibility. Nutrition Research Reviews, 15(1), 169-206. http://dx.doi.org/10.1079/NRR200131

Gordon, N. (2003). Iron Deficiency and the Intellect. Brain and Development, 25(1), 3-8. http://dx.doi.org/10.1016/s0387-7604(02)00148-1

Khalil, M. M. B. (2003). Scale of Social, Economic, and Cultural Level for Egyptian Family in the Deviation of Youth in the Era of Globalization, FAQ Brochure. Cairo: Qobaa House for Printing and Publication.

Khaled, Z. K., \&Yahya, S. H. (2010). Effectiveness of a Computer Program for Food Culture on the Elementary Stage Students' Achievement and Nutritional awareness. College of Education Journal, Benha University, 19, 98.

Klenman, E., Hall. H., Green, D., Korzec, M., Ramirez, K., Patton, E., \& Pagano, M. (2002). Diet, Breakfast and Academic Performance in Children. Annals of Nutrition Metabolism, 46(1), 24-30. http://dx.doi.org/10.1159/000066399

Michaud, C. M., Nicola, J., \& Mejean, L. (1991). Effects of Breakfast Size on Short Term Memory, Concentration, Mood and Blood Glucose. Journal of Adolescence Health, $12(1), \quad 537$. http://dx.doi.org/10.1016/0197-0070(91)90042-K

Miryah, F. (2012). Learner's Malnutrition and its relationship with Academic Achievement, (MA. Thesis), College of Social Sciences, Wahran University, Algeria.

Mohammed, A. A. (2006). The Lack of Pre-Academic of Kindergarten and Learning Disabilities Children. Cairo: Al-Rashad House.

Mohammed, L. A. (1985). The Relationship among Nutrition Level, Intelligence, and Social and Psychological Compatibility among children at Elementary Stage, (Unpublished Ph.D. Dissertation), Al-Azhar University, Cairo

Pollitt, E., Leibei, L., \& Greenfield, D. (1981). Brief Fasting Stress and Cognition in children. American Journal of Clinical Nutrition, 34, 1526-1533.

Polloway, E. A., Epstein, M. H., \& Foley, R.M. (1992). A Comparison of the Homework Problems of Students with 
Learning Disabilities and non-handicapped Student teachers. Learning Disabilities Research and Practice, 27(8), 500-510. http://dx.doi.org/10.1177/002221949402700805

Saba, N. H. (2010). Cocking as Science and art (2nd Ed.). Cairo: Ma'aref House.

Scrimshaw, S. (1998). Malnutrition, Brain Development, Learning, and Behavior. Nutrition Research, 18(2), 351-379. http://dx.doi.org/10.1016/S0271-5317(98)00027-X

Shalabi, S. M. (2001). Food and Medicine health. Cairo: Ma'aref House.

Shehda, S. A. (1992). Nutritional Awareness among Children of the Elementary Stage. Fourth International Conference towards Better Basic Education, Alexandria, August, 3-6, 1-19.

Sherratt, E. (1996). High Fat Intakes Unhealthy but Do Children Know? ERIC NO: EJ526950.

Soroor, A. A. (1994). A Proposed Program for Rural Woman Health Education and its Efficacy in Providing her with Concepts and Attitudes Related to Health Awareness, An Empirical Study in Some Villages of Dakahlia District. College of Education Journal, Mansoura University, (30).

Suleiman, A. A., \& Hasaneen, M. M. (1997). Health Status of the Egyptian Woman: Studies about the intellectual Framework of Woman Component in the Fourth Five-Year Plan for Economic and Social Development, National Council for Motherhood and Childhood.

Wahba, S. A., Mekawy, A. A., Taha, R. M., \& Mohsen, W. A. (1998). Breakfast Skipping and Dietary Adequacy of Primary Schools Children in Cairo. Journal of Arab Child, 90(4).

Yousef, M. K. (1994). Egyptian Encyclopedia in Human Nutrition (1st Volume). Alexandria: Arabic House for Publication and Distribution.

Zhang, J., Hebert, R., \& Muldoon (2005). Dietary Fat Intake is Associated with Psychosocial and Cognitive Functioning of Children in the United States. Journal of Nutrition, 135(8), 1967-73. 